\title{
Management of Growing-Season Grazing in the Sagebrush Steppe
}

\section{A Science Review of Management Tools Appropriate for Managing Early-Growing-Season Grazing}

\author{
By J. W. Burkhardt and K. Sanders
}

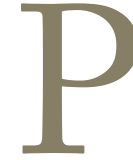

roper livestock-grazing management and the maintenance of native shrub-bunchgrass vegetation are critical concerns throughout the Intermountain West. Lower-elevation sagebrush-steppe communities have long been used as early-spring grazing areas and are an important forage source for livestock and wildlife (Fig. 1). Protein-rich, spring forage is critically important in the reproductive cycle of all herbivores. The very short, spring growing season is also critical to maintaining healthy perennial forage plants and should be the focus of grazing management when spring grazing occurs. However, techniques commonly used by agency personnel to determine appropriate stocking rates, such as measures of use or ocular use estimates, are not appropriate or adequate methods to manage growing-season grazing. Because plant growth during the spring growing season is a constantly changing variable, these techniques do not adequately assess the effects of spring grazing. Therefore, management of spring grazing should be based on the phenology cycle of key bunchgrasses in the sagebrush plant community.

In this article, we provide an overview of grazing research primarily focused on management of early-growing-season grazing in lower-elevation sagebrush steppe. Our review is based on existing research, combined with our many years of grazing-management experience.

\section{Climate and Vegetation}

Environmental conditions common to the lower elevation or more xeric parts of the sagebrush steppe (southern Idaho, northern Nevada, eastern Oregon, northern Utah, eastern Washington) are arid (8-12 inches precipitation), predominantly, cold-season precipitation; relatively mild winters; short spring growing season (approximately 6 weeks); hot, dry summers; and rare fall green-ups. The vegetation commonly found under these environmental conditions is the Wyoming big sagebrush plant community with a perennial grass understory. This sagebrush vegetation is widespread throughout the Snake River Plain of southern Idaho, across northern Nevada and Utah, eastern Oregon, and the Columbia Basin of eastern Washington. Native bunchgrasses, such as bluebunch wheatgrass (Pseudoroegneria spicata), Thurber's needlegrass (Achnatherum thurberianum), squirreltail (Elymus elymoides), and Sandberg bluegrass (Poa secunda), are well-adapted to these environmental conditions. The native sagebrush-steppe vegetation evolved with, and is adapted to, periodic fires. ${ }^{1}$ Unfortunately, a suite of exotic annual weeds can also thrive. Cheatgrass (Bromus tectorum), an invasive, annual grass, can establish dense monocultures on disturbed sites allowing rapid fire spread compared with the patchy fuels of native bunchgrasses. Cheatgrass invasion radically increases the frequency and extent of wildfires, well beyond the natural role of fire in the lower sagebrush steppe. Frequent cheatgrass-fueled fires kill sagebrush and weaken native, perennial grasses, which did not evolve with frequent fire. This can create self-sustaining, annual grass monocultures where sagebrush/bunchgrass once existed.

\section{Grazing Research Issues}

Land management agencies, such as the Bureau of Land Management or the US Forest Service, are expected to base their management plans on the best available science. Certainly, there are many research articles published in scientific journals regarding various aspects of rangeland ecosystems. Yet, well-designed and replicated grazing management research, especially in the intermountain sagebrush steppe, is remarkably lacking. ${ }^{2,3}$ Rangeland ecology research is highly site specific. The most appropriate and applicable research are those studies conducted on the same or similar ecological sites as the area being managed. The vast expanse and variability of rangelands and the lack of grazing-herd control virtually precludes the strict application of the scientific method or critical experiment to rangeland grazing management. ${ }^{4} \mathrm{Be}-$ cause of this, even the conclusions in the journal Rangeland Ecology E Management or other "scientific" natural-resource publications on grazing studies are often debatable, inconclusive, and may not be representative of conditions beyond the particular study. 
When dealing with biological organisms, there are many variables that research scientists cannot control, and this makes it difficult to conduct replicated, controlled research studies and then make statistical inferences. For example, rangeland scientists have no control on weather, little control on grazing animals (especially wildlife) over vast landscapes, and have limited opportunities for replications because of the physical variability of rangelands. ${ }^{5}$ Heady ${ }^{6}$ calculated that if the number of all variables (weather, multiple ecological sites, and grazing animals) were multiplied together, the total number of pastures needed to study all permutations, with acceptable confidence, would be 13,000. In contrast, crop scientists generally deal with one plant species, have multiple replications on the same type of soil, slope, and aspect; have the ability to control soil moisture on irrigated fields; and generally focus on the growing season. Furthermore, animal scientists can manage certain variables with research animals because they are tame.

Conclusions-based grazing management studies are problematic because of the many variables of rangelands in research. The advancement of grazing management knowledge is best accomplished when practical experiences and science are the basis for management. Scientific research in plant ecology, physiology, and species response to experimental treatments, coupled with many decades of grazing management experience has advanced the art of grazing management. Rangeland management of necessity is an art as well as science. Science can provide managers with expected resource responses to certain treatments under specific conditions. The art becomes the manager and the rancher adapting, applying, and tracking the response, then, based on that response, adjusting and reapplying management to meet stated goals. There is no "cookbook" prescription for good grazing management. It is a continual process of application, monitoring, adjustment, and reapplication, otherwise known as adaptive management.

\section{Some Relevant Background Information}

\section{Plant Regrowth}

Research and practical experience have demonstrated that plant response to herbivory varies with plant species, degree and season of defoliation, weather conditions, and plant vigor. Generally, defoliation has greater negative effects on the plant if it occurs during the active growth period than if it occurs during dormancy. ${ }^{3}$ Perennial grasses use carbohydrates stored in their root systems for respiration during dormancy and to initiate spring growth.

Restoration of root systems and replenishment of carbohydrate reserves is not complete until after seed set. ${ }^{7}$ However, leaf regrowth after removal during the growing season comes from photosynthesis, rather than stored carbohydrates. ${ }^{8}$ Regrowth can take place quickly if bunchgrass growing points remain intact. The growing points (meristematic stem inflorescence tissue) in bunchgrasses common to sagebrush plant communities do not elevate early enough to be damaged by reasonable levels of early-spring grazing. Richards and Caldwell ${ }^{9}$ found that within 3 days of severe defoliation the rate of photosynthesis on both crested wheatgrass (Agropyron cristatum) and bluebunch wheatgrass exceeded the plants' need for respiration and regrowth when defoliation occurred early in the growing season and soil moisture was adequate to support plant growth.

In contrast, late-growing-season grazing can interrupt or even preclude the forage plant from completing its annual phenologic cycle. Clipping studies clearly demonstrate the adverse effects of severe, late-growing-season defoliation on bluebunch wheatgrass. ${ }^{10}$

\section{Grazing Systems}

Briske and colleagues ${ }^{4}$ sparked intense discussion of the merits of different grazing systems. They reviewed published grazing studies and found that rotational grazing, compared with season-long grazing, rarely increases plant or animal production on either a per-head or a per-area basis. They suggest that rest periods often occur while plants are not actively growing, hence providing limited benefits. Instead, they indicate that differences in stocking rate and variations in weather are the most important determinants of plant and animal production. Few of the reviewed studies were conducted on sagebrush/bunchgrass rangelands. Although Briske and colleagues evaluated the effect of grazing systems on total forage production, they did not address the effect of selective grazing on plant community composition. Grazing animals select the most palatable plants first, putting these plants at a competitive disadvantage, especially during the growing season. Plant community composition is an important consideration when managing grazing on sagebrush/ bunchgrass rangelands. Stands of vigorous perennial grasses with sagebrush and perennial forbs provide a stable forage supply and wildlife habitat while protecting soil resources.

As previously mentioned, rangeland ecology research is highly site specific. There have been relatively few grazing studies on sagebrush rangelands despite 120 years of grazing experience. Only two of the grazing studies reviewed by Briske et al. ${ }^{4}$ were conducted on sagebrush/bunchgrass rangelands although numerous clipping studies have been conducted.

\section{Seasonal Grazing}

Hyder and Sawyer ${ }^{11}$ conducted a 10 -year grazing study on sagebrush/bunchgrass rangeland at the Squaw Butte Experiment Station in Oregon (now the Eastern Oregon Agricultural Research Station). They found differences in forage production with different seasons of use under rotational grazing. Two consecutive years of spring grazing reduced forage yields considerably. Overall, perennial grasses were larger and more vigorous, but not more dense, with rotational grazing. Their study suggests that consecutive years of spring grazing can reduce plant growth and forage yields. It also 
suggests that rotational grazing can result in more-vigorous perennial grasses, compared with continuous grazing.

Vigorous, perennial grasses are preferred for most uses of sagebrush/bunchgrass rangelands. Although rotational grazing cannot induce a site to produce more vegetation than it is ecologically capable of, the Hyder and Sawyer ${ }^{11}$ study suggests that altering the season of grazing to the forage-plant reproductive stage can alter vegetation composition over time. Furthermore, consecutive years of spring grazing are likely to be detrimental to these areas. Competition from associated species can also influence regrowth following defoliation more than the intensity of defoliation does. ${ }^{12}$

Later research from the Squaw Butte Experiment Station identified the early boot stage of Thurber's needlegrass growth as the most susceptible to reduced vigor from grazing. ${ }^{13}$ Effects from grazing were progressively less severe during early vegetative growth and late seed set. The author suggested that a single defoliation during the boot stage (initial seed set) can significantly reduce subsequent growth, both aboveground and belowground. This study suggests that Thurber's needlegrass, a common perennial grass in lowerelevation sagebrush steppe, should be grazed either before or after the boot stage and further suggests that other perennial grasses likely respond similarly.

Spring defoliation of bluebunch wheatgrass on sagebrush/ bunchgrass rangelands in Utah and interior British Columbia that extends late enough to preclude regrowth before summer dormancy significantly reduced plant survival and vigor the following year. ${ }^{10,14}$ Neither severe defoliation in the fall nor season-long light defoliation significantly damaged bluebunch wheatgrass plants in British Columbia. These studies suggest that bluebunch wheatgrass, a common perennial grass in lower-elevation sagebrush steppe, is particularly sensitive to heavier levels of late-growing-season defoliation.

Sharp ${ }^{15}$ recommended a deferred rotation system consisting of at least two crested wheatgrass pastures in south central Idaho. With this approach, cattle are removed from the earlyspring grazed pasture while sufficient soil moisture remains for regrowth. This study suggests that early-spring use should be alternated between the pastures in a 2-year cycle.

\section{Management of Spring Grazing}

\section{Challenges of Quantifying Spring Grazing With Use Methods}

Many years of grazing experience as well as published studies have demonstrated the importance of conservative stocking rates, regardless of the grazing system., ${ }^{2,16}$ Some form of use assessment and past stocking rates are necessary tools to arrive at reasonable stocking rates for season-long grazing or grazing that occurs after the growing season. Most federal grazing permits contain terms and conditions that limit grazing use levels. However, we believe, as did Western Coordinating Committees ${ }^{17}$ and Smith et al. ${ }^{17}$ that use rate is just a tool and is not the management-plan objective or an appro-

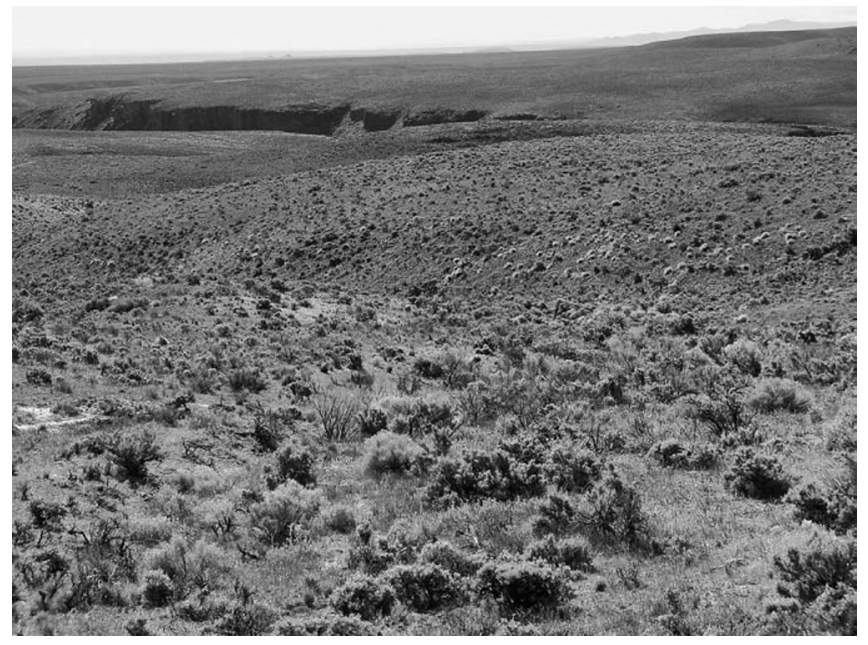

Figure 1. Typical intermountain sagebrush/bunchgrass spring range.

priate term and condition for permits, especially on spring grazing permits.

Management variables for early-spring grazing include the date grazing starts and ends, duration of grazing, stocking rate, and timing relative to plant phenology. For early-growingseason grazing, we believe "utilization" is impractical to obtain and is of questionable biological significance. Utilization is the amount of annual forage growth removed, expressed as a percentage of the total annual growth. Rather than focusing on methods for quantifying early-season grazing, we believe the focus should be on methods to effectively manage early-season grazing. Actual grazing use is sufficiently quantified by stocking rate, duration, and season of use. Effects on the plant community are assessed by long-term trend.

Certainly, in theory, the degree of defoliation based on amount of plant growth to that point in time (relative use or seasonal use) could be quantified. Interpreting biologic significance to forage plants becomes questionable. The degree of defoliation during early-growing-season grazing is based on a continuously changing denominator and has little biological significance or management utility. The amount of plant growth at the time of measurement is not a biologic constant like the total annual growth or the peak production. Does 50\% tissue removal 2 weeks into the growing season have the same effect on plant physiology as 50\% removal near the end of the growing season? For example, Ganskopp ${ }^{13}$ demonstrated that clipping Thurber's needlegrass to 1 inch during different phenologic stages affected the plant differently. Other studies demonstrated similar results on bluebunch wheatgrass. ${ }^{10,14}$ The later the defoliation occurs within the bunchgrass reproduction stages, the greater the negative effects will be on the plant, especially if repeated year after year.

We believe that basing early-season grazing on relative use is much too simplistic to ensure proper grazing. ${ }^{18}$ It imposes practical problems on the land manager if timely assessment of relative use is to be accomplished, aside from the issue of biological significance. During the active spring-growth 
period, the amount of residual plant material at the end of the grazing period changes daily. It would be impractical, if not impossible, for management agencies with numerous spring-grazing allotments to even assess relative use immediately after livestock are removed. Certainly, some amount of residual green tissue should remain on forage plants when spring grazing stops for the year, but we believe there are other more-effective tools for managing early grazing and ensuring healthy plant communities.

\section{Plant Physiology and Grazing}

The sagebrush/bunchgrass ranges of the Intermountain West evolved with some level of early-growing-season grazing. ${ }^{19}$ Naturally, some level of early-season grazing is a necessity for range livestock operations and big game alike. Research and practical experience have shown that healthy sagebrush/ bunchgrass ranges can be maintained under early-growingseason use. ${ }^{13,14}$ This can be accomplished by providing the grazed plants the opportunity to complete their reproductive cycle at least every other year.

Although production of viable seed is certainly a prerequisite to long-term survival of bunchgrasses, yearly seed production usually far exceeds what is necessary for long-term maintenance of bunchgrass populations. However, intact, elongated growing points later in the growing season are necessary for restoration of annual root dieback and replenishment of carbohydrate reserves. These are more critical requirements than seed production and are only accomplished after seed set.

\section{Management Approaches}

Two management approaches have proven successful at providing bunchgrasses with adequate seed production and carbohydrate storage opportunities under growing-season grazing. A system of "early on-early off" or a two to three early-season pasture rotation allows grazed bunchgrasses to complete their reproductive cycle without grazing interruption, at least on alternating years, if not every year.

If growing-season grazing occurs each year on the same range unit, then the crucial management tool is controlling when that season's grazing-use ends. Livestock must be removed early enough to ensure sufficient remaining growing season (soil moisture) to allow forage plant regrowth and completion of the reproductive cycle. From a plant physiology standpoint, it is more important when the grazing use stops than when livestock come onto the range. Early-spring turn-on dates are more of an animal consideration, whereas the time of animal removal is driven by plant regrowth and soil moisture. For example, in southern Idaho, late May is generally the time to move off a pasture of crested wheatgrass to ensure regrowth. ${ }^{15}$

Early on-early off is essentially where the grazing animals "follow the green," tracking fresh, green forage up the elevational gradient of the mountain. This most likely approximates the natural system of wildlife herbivory that the sagebrush steppe evolved under and today works best with herded sheep. ${ }^{19}$ For range ewes to produce fat lambs by late August, the summer bands need to be continuously moving to fresh, green forage. Forage plants can then complete their reproductive cycle after the animals have moved off. This is especially critical on the arid and semiarid salt-desert shrub and sagebrush ranges. If herds are slowly grazing their way up the mountain and not circling back to regraze areas already used, then the amount of residual stubble should not be a critical issue (once-over grazing). Leaving 3 to 4 inches of residual foliage on primary, perennial forage species, behind the moving herd, will allow plant growth to continue, and phenologic development to be completed. As previously noted, the rate of photosynthesis within 3 days of severe defoliation on two species of wheatgrass exceeded the plants' need for regrowth and respiration. ${ }^{9}$ This research does not support the application of conservative utilization levels as the management criteria when sufficient growing period and soil moisture remains after grazing use.

With fenced pastures or allotments and unherded cattle, the early on-early off management strategy becomes more difficult. The tendency is to leave cattle in place as long as there is adequate forage or until some moderate level of use has been reached. From a soil-moisture and plant-regrowth perspective, that is nearly always too late to ensure grazed plants the opportunity to complete their reproductive cycle.

Where it would be difficult to follow the green with cattle, a system of two to three early-spring pastures at similar elevations could be used. This would ensure that forage plants could periodically complete their reproductive cycle without being completely grazed before seed maturity. Under this rotation, the timing of pasture moves is much less critical. The pasture that receives critical growing-season use one year is not grazed during the next growing-season, allowing forage plants to complete their reproductive cycle without grazing on alternate years. A system with three early-use pastures could provide plants with 2 out of 3 years to complete seed production and restore root system carbohydrates. This might be necessary when range conditions are less than healthy. The amount of residual stubble remaining after grazing use under a growing-season rotation is less a plant concern than it is a watershed/habitat issue. This is because there may be little or no growing-season soil moisture remaining to support regrowth after the end of the early-pasture-grazing period. In the other pasture, grazing is deferred until after seed set.

Under either early-season grazing strategy, the measure of management success or failure is the changes in the plant community over time (trend) rather than tracking relative use. The range profession has long advocated the use of long-term trend monitoring to determine the effects of grazing systems. ${ }^{7}$ Other monitoring data, such as use and weather, are useful in interpreting trend. However, with early-growing-season grazing, utilization is not an appropriate measure of management success or as terms and conditions in grazing permits. ${ }^{20,21}$ 


\section{Trend Monitoring}

We believe that an extensive, rather than intensive, trend-monitoring system is an important part of any grazing management program. Rangeland grazing is an extensive land use over vast and variable landscape expanses. We recommend a relatively simple, permanent, photo-point trend-monitoring system that includes both landscape and close-up photos. When possible, photographs should be repeated annually. Photos should adequately document any significant positive or negative changes in plant composition without creating an excessive workload.

The usefulness of photo monitoring for evaluating changes in plant communities has been well documented. ${ }^{22,23}$ In situations where annual photo monitoring may not provide sufficient trend information, quantitative methods may also be used. In addition to trend monitoring, we believe it is important to annually monitor behind follow-the-green grazing to ensure primary forage plants do, in fact, regrow and set seed. Under early-growing-season rotations, it is important that plants in at least one pasture complete the reproductive cycle each year.

We recommend that the range specialist and the livestock manager conduct field monitoring together. This is a prerequisite to joint problem solving and good grazing management. Joint monitoring is the basis for building effective local knowledge of the effects of grazing. Monitoring and knowledge of local growing conditions will provide the livestock manager and the range specialist with the necessary information to make decisions for moving livestock.

\section{Grazing and Sage Grouse}

The early-season grazing strategies previously discussed are compatible with sage-grouse nesting concerns. Grazing schedules that provide bunchgrasses the opportunity to fully develop to maturity provide sage-grouse nesting cover in the interspaces around sagebrush nest sites. Following-the-green grazing strategies allow bunchgrass development each year following early grazing. Early-grazed pasture rotation provides at least one ungrazed pasture each year for sage-grouse nesting. Fischer and colleagues ${ }^{24}$ found sage-grouse hens displayed nesting fidelity to general areas but not specific nest locations. This may allow hens to choose to nest in ungrazed pastures within the general area.

\section{Grazing and Riparian Areas}

These strategies for managing early-growing-season grazing are also compatible with riparian resources. ${ }^{25}$ Grazing during the cooler spring time when upland forage is still green and lush tends to minimize livestock use of creek bottoms. When livestock move out of spring pastures, riparian plants have the entire summer hot season to recover from any grazing effects that may have occurred during the early-spring use.

\section{Other Considerations}

Grazing rotations that allow forage plants the opportunity to regrow following early-spring use result in benefits beyond healthy perennial grasses. Both palatability and nutrient con- tent increases compared with ungrazed, mature forage plants. Sharp ${ }^{15}$ found that yearling cattle grazing spring regrowth in the fall nearly doubled the weight gain of yearlings grazing on pastures left ungrazed until fall.

Anderson and Scherzinger ${ }^{26}$ found that early-spring cattle grazing on the Bridge Creek Game Range in Oregon increased wintering elk populations compared with areas with no spring cattle use. This response in the elk population was due to increased palatability and nutrient content of forage regrowth. The regrowth tends to have a higher ratio of leaves to stems and higher crude protein than ungrazed plants. Spring grazing at a higher intensity also reduces the fine fuel and the chance and intensity of wildfire during the dry season. This can be important on lower-elevation ranges dominated by cheatgrass prone to frequent fires.

\section{Summary}

We believe that growing-season grazing on sagebrush/ bunchgrass rangelands warrants special management attention. Research and practical experience both have shown that bunchgrasses common to the sagebrush plant communities are much more sensitive to growing-season grazing than they are to dormant season use. Furthermore, that sensitivity relates to the timing of growing-season use relative to the plant reproductive cycle. Defoliation early in the growing season has less negative impact to bunchgrasses than it does during the flowering period. Consequently, we believe that the focus of management for growing-season grazing should be on ensuring that primary, perennial forage grasses are allowed to complete seed set at least every second year.

In our opinion, the concept of measuring forage use or basing management on achieving some conservative utilization standard is inappropriate for growing-season grazing. When use is measured during the growing season, the amount of plant growth is a constantly changing variable with no common biologic basis. Clipping studies, for example, have shown that $50 \%$ defoliation 2 weeks into the growing season has less effect on bunchgrasses than does $50 \%$ defoliation in the late growing season. In addition, there are very real, practical restraints in obtaining timely growing-season use measurements on which to base management decisions.

We believe that the measure of grazing management success or failure is tracking changes in the plant community over time. Monitoring trend is fundamental to the management of rangeland grazing. This can be easily accomplished using permanent photo locations and should be conducted jointly by the agency range staff and the permittee or livestock manager.

\section{References}

1. Burkhardt, J. W., and E. W. Tisdale. 1976. Cause of juniper invasion in southwestern Idaho. Ecology 57:472-484.

2. Eckert, R. E., and J. S. Spencer. 1987. Growth and reproduction of grasses heavily grazed under rest-rotation management. Journal of Range Management 40:186-189. 
3. Miller, R. F., T. J. Svejcar, and N. E. West. 1994. Implications of livestock grazing in the intermountain sagebrush region: plant composition. In: M. Vavra, W. A. Laycock, and R. D. Pieper [EDs.]. Ecological implications of livestock herbivory in the West. Denver, CO, USA: Society for Range Management.

4. Briske, D. D., J. D. Derner, J. R. Brown, S. D. Fuhlendorf, W. R. Teague, K. M. Havstad, R. L. Gillen, A. J. Ash, and W. D. Williams. 2008. Rotational grazing on rangelands: reconciliation of perception and experimental evidence. Rangeland Ecology \& Management 61:3-17.

5. Caldwell, M. M. 1984. Plant requirements for prudent grazing. In: National Resource Council/National Academy of Science [EDS.]. Developing strategies for rangeland management: a report prepared by the Committee on Developing Strategies for Rangeland Management. Boulder, CO, USA: Westview Press. p. $117-152$.

6. Heady, H. F. 1974. Theory of seasonal grazing. Rangeman's Journal 1(2):37-38.

7. Stoddart, L. A., A. D. Smith, and T. W. Box. 1975. Range management. 3rd ed. New York, NY, USA: McGraw-Hill Book Company, Inc. 532 p.

8. Briske, D. D., ANd J. H. Richards. 1995. Plant responses to defoliation: a physiological, morphological and demographic evaluation. In: D. J. Bedenah and R. E. Sosebee [EDs.]. Wild plants: physiological ecology and developmental morphology. Denver, CO, USA: Society for Range Management.

9. Richards, J. H., And M.M. Caldwell. 1985. Soluble carbohydrates, concurrent photosynthesis and efficiency in regrowth following defoliation: a field study with Agropyron species. Journal of Applied Ecology 22:907-920.

10. Stoddart, L. A. 1946. Some physical and chemical responses of Agropyron spicatum to herbage removal at various seasons. Logan, UT, USA: Utah State Agricultural College, Agricultural Experiment Station. Bulletin 324. 24 p.

11. Hyder, D. N., And W. A. Sawyer. 1951. Rotation-deferred grazing as compared with season-long grazing on sagebrushbunchgrass ranges in Oregon. Journal of Range Management 4:30-34.

12. Mueggler, W. F. 1972. Influence of competition on the response of bluebunch wheatgrass to clipping. Journal of Range Management 25:88-92.

13. Ganskopp, D. 1988. Defoliation of Thurber needlegrass: herbage and root response. Journal of Range Management 41:472-476.

14. McLean, A., And S. Wikeem. 1985. Influence of season and intensity of defoliation on bluebunch wheatgrass survival and vigor in south British Columbia. Journal of Range Management 38:21-26.

15. Sharp, L.A. 1970. Suggested management programs for grazing crested wheatgrass. Moscow, ID, USA: University of Idaho Forest, Wildlife and Range Experiment Station. Bulletin 4.

16. Ellison, L. 1960. Influence of grazing on plant succession of rangelands. Botanical Review 26:1-78.

17. Western Coordinating Committees 40 and 55. 1998. Stubble height and utilization measurements: uses and misuses. Corvallis, OR, USA: Oregon State University Agricul- tural Experiment Station. Bulletin 682. Available at: http:// ir.library.oregonstate.edu/xmlui/bitstream/handle/1957/15884/ StationBulletin682.pdf. Accessed 30 June 2011.

18. Sharp, L., K. Sanders, and N. Rimbey. 1994. Management decisions based on utilization - is it really management? Rangelands 16:38-40.

19. Burkhardt, J. W. 1996. Herbivory in the Intermountain West: an overview of evolutionary history, historic cultural impacts and lesson from the past. Moscow, ID, USA: Forest, Wildlife and Range Experiment Station, University of Idaho. Bulletin 58. 35 p.

20. Smith, L., G. Ruyle, J. Maynard, S. Barker, W. Meyer, D. Stewart, B. Coulloudon, S. Williams, and J. Dyess. 2007. Principles of obtaining and interpreting utilization data on rangelands. Tucson, AZ, USA: University of Arizona College of Agriculture and Life Sciences. Report AZ1375. Available at: http://cals.arizona.edu/pubs/natresources/az1375.pdf. Accessed 30 June 2011.

21. University Of Idaho Stubble Height Review Team. 2004. University of Idaho stubble height study report. Moscow, ID, USA: Forest, Wildlife and Range Experiment Station, University of Idaho. Contribution 986. Available at: www.cnr.uidaho.edu/range/pubs/Stubble_Height_Report. pdf. Accessed 30 June 2011.

22. Sharp, L. A., K. Sanders, And N. Rimbey. 1990. Forty years of change in a shadscale stand in Idaho. Rangelands 12:313-328.

23. Bennett, L. T, T. S. Judd, and M. A. Adams. 2000. Close-range vertical photography for measuring cover changes in perennial grasslands. Journal of Range Management 53:634-641.

24. Fischer, R. A., A. D. Appa, W. L. Wakkinen, and K. P. Reese. 1993. Nesting area fidelity of sage grouse in southeastern Idaho. Condor 95:1038-1041.

25. Mosley, J. C., P. S. Cook, A.J. Grifs, and J. O'Laughlin. 1997. Guidelines for managing cattle grazing in riparian areas to protect water quality: a review of research and best management practices policy. Moscow, ID, USA: University of Idaho Analysis Group. Report 15.

26. Anderson, E. W., And R. J. Scherzinger. 1975. Improving quality of winter forage for elk by cattle grazing. Journal of Range Management 28:120-125.

\section{Additional Reading}

Pieper, R. D. 1994. Ecological implications of livestock grazing. In: M. Vavra, W. A. Laycock, and R. D. Pieper [eds.]. Ecological implications of livestock herbivory in the West. Denver, CO, USA: Society for Range Management. p. 177-211.

Authors are Associate Professor Emeritus, Dept of Range Management, University of Nevada, Reno, Reno, NV 89557, USA, and Consultant, Ranges West, Weiser, ID 83672, USA, rangeswest@ ctcweb.net (Burkhardt); and Professor Emeritus, Dept of Range Extension and Grazing Management, University of Idaho, Moscow, ID 83844, USA (Sanders). This paper results from an unpublished report commissioned by the Owyhee Initiative and the University of Idaho Rangeland Center. 